\title{
DOWN RIVER BY CAR
}

\section{By Mervyn Cowie, Director, Royal National Parks of Kenya}

Seldom would one think of going down a river by car, but it all depends on the river and on the car. "Bush-busting" with two four-wheel drive cars for 20 miles from Kimathena brought us to the palm-fringed banks of the Tiva-a dry water-course with a wide expanse of gleaming sand, washed white by successive rainy seasons.

Water is, of course, the essential feature of any dry part of Africa, and here in the Tiva nature has designed a strange association of living things, where all creatures depend on the river, and to a great extent on each other, for their very existence. Rain that falls on the hills of Ukambani finds its way down the Tiva-when in flood on the surface-but for most of the year under the sand. A perfect system of filtration is in action, and the water seeps slowly through-but not too slowly to travel 100 miles almost to Ndiandaza.

Elephants provide the next essential component in this scheme of things, for these wise old beasts know now to dig in the sand and many other animals rely on them to make the waterholes. The process is to scrape away the sand with their trunks in a slanting hole, deep enough for the water to percolate through and form a small pool, sometimes 4 feet below surface. Drinking is then as much a ritual as it is with humans, but more patience is required. The older elephants know that it is best to wait after digging for the water to collect and clear, before sucking it up with their trunks and squirting it into their mouths. Reserve tanks have to be filled, babies have to be schooled, and washing has to be completed before the performance is over. This may take a herd many hours to achieve. Impatient youngsters are often lambasted for spoiling a hole before it is ready, and family discipline has to be of a very high order.

Then other creatures, less equipped to dig, come in to drink in the holes made by the elephant. Rhino often arrive next, or even drive the elephant out, and with much snorting and blowing they struggle to get at the water. Through some mean trait in their character, they often close the holes after they have had their fill, perhaps to spite the other animals who compete with them for the juicy riverine vegetation, or perhaps just because they are so stupid.

Lion, buffalo, eland, zebra, giraffe and various small antelope also depend on the water made accessible by the elephants, and it is not uncommon to see a kudu with his hind-quarters 


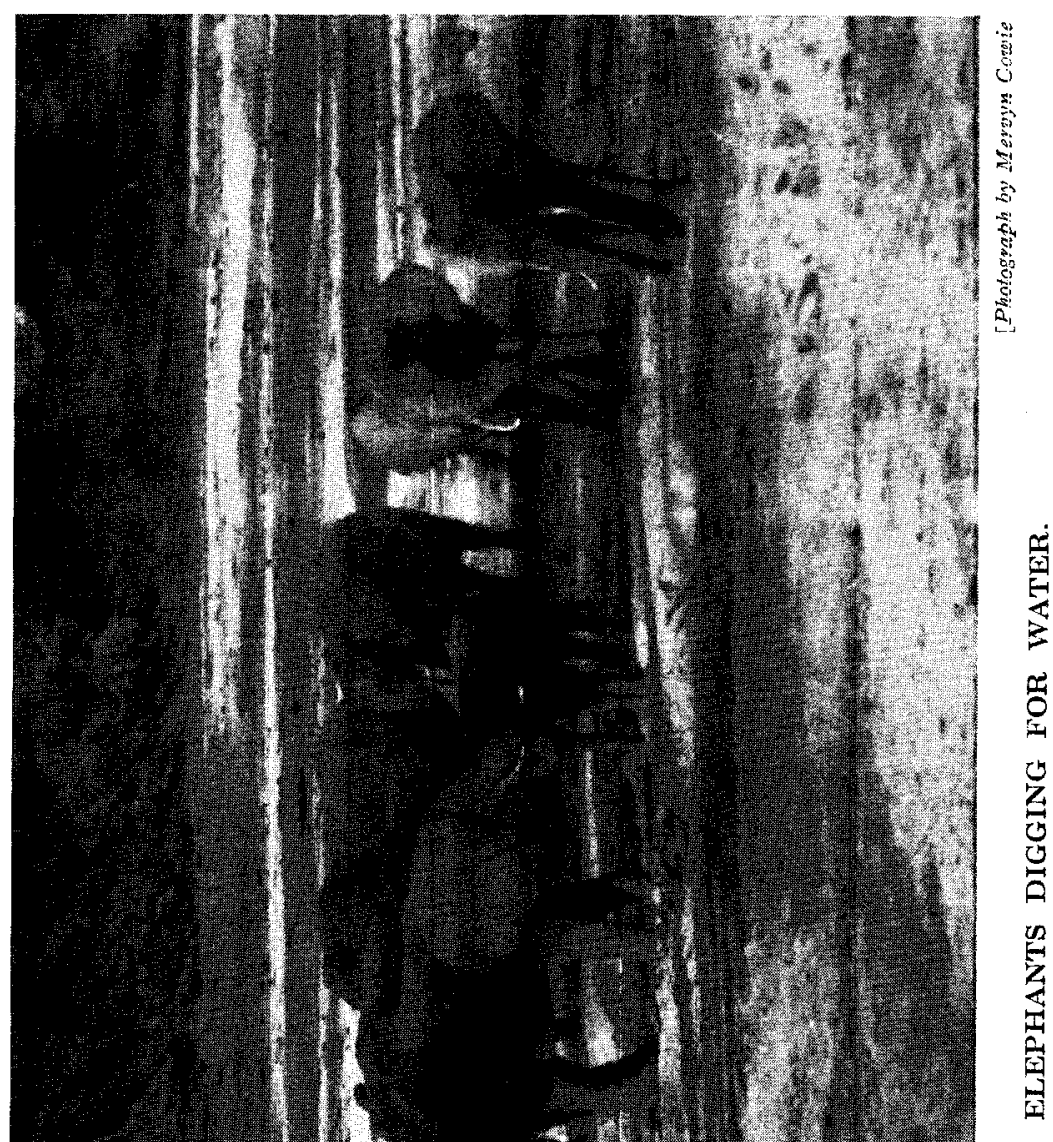


protruding above the sand while his head and horns are well down below. These shy creatures have great difficulty in obtaining a peaceful drink for after each sip they deem it necessary to stand erect and watch and listen for some unseen enemy. If alarmed, they bound away, flicking their white tails and barking like a dog.

Baboons and monkeys, although quite capable of doing their own excavations, also use the elephant holes. They travel far to find a shallow place, possibly due to some instinctive dislike of crawling underground.

Birds, reptiles and small rodents, all seem to recognize the importance of the elephants and so treat them with respect. Great flights of sandgrouse and doves swish in and out of each group of pools. They cluster so closely that any sudden disturbance makes it impossible for them all to fly at once. Many a predatory cat takes advantage of this situation and the usual drinking places are littered with feathers of birds that fail to take off in time. Last, and in this case least, are the butterflies, bees and tiny creeping things that also want a drink.

I wondered as we travelled down the sand what would happen to the sequence of life if the lumbering old elephants failed in their self-imposed duties of water-purveyors-in-chief to this part of the animal kingdom. I felt tempted to institute the construction of a series of concrete walls to provide surface water for all these animals as a reasunable obligation of the national parks service, but I soon decided it would be unsuccessful. One flood and all the dams would be covered in sand, and even if they were not I have already realized that man in all his wisdom [sic] cannot improve on the methods of nature. For generations, or perhaps thousands of years, this strangc process has gone on, and it is only another remarkable aspect of the balance of nature.

Although the surface of the river bed was for the most part even and relatively hard, there were some quite difficult stretches, and progress was slow. Sandbanks and old drinkingholes held out a challenge to our amazing mechanical transport and called for a high standard of driving skill. Each stop to allow elephants right of way, or to watch some strange episode of nature, meant serious delay, for once a laden vehicle is halted on loose sand, the wheels sink deep. One of our cars objected to this heavy treatment and we located the fault as being a reluctant spark plug. All the engineering skill and ingenuity we could muster failed to solve the problem.

It was here that I experienced the astonishing power of modern science in a setting which by contrast was wholly 
primitive. A radio message to base soon started two African rangers off at full speed through the bush, carrying a small precious parcel of plugs. Lightly equipped, and with only a brief description of our rendezvous, they travelled fast through unfriendly thorns, across the Galana river, and over Yatta escarpment in the dark. This would seem an impossible task to anyone but these hard trackers, who covered the $\mathbf{3 0}$ miles to our camp before noon the following day. The small parcel was to them an absurd object for such a journey, but in the old African fashion they accepted the white man's wishes without question, and the errand as a challenge which no proud hunter could refuse.

Arriving calmly as if back from a stroll, and after a long drink, taken like a kudu, with heads down and tails up, they started to relate the excitements of the night. New energy suddenly became available for them to re-enact, with realistic noises, how a rhino had charged between them and how an elephant, in the gloom, had very nearly been chosen as a suitable rock for shelter-until it moved. Before the rangers settled down to pulling out thorns and mending their sandals, the new plugs proved entircly successful, and we were soon on our way down the sand again until darkness forced another halt.

Camp at the end of a long hot day is always welcome, but this one was also exciting. Camping is perhaps not the best description, for it amounted to a bed on the sand and a fire up and downstream. We were obviously not the only users of the river as a road and footprints indicated that many animals travelled the same route. Some precaution had to be taken, so that we were not trampled by a resentful herd of elephant, or routed by a touchy rhino, who under these circumstances would have all the advantages and something of the appearance of an express train.

The remarkable thing about wild Africa is the silence-or noise-of the night. There are moments when there is absolutely no sound whatever. Then there is a rustle in the dom palms; a lonely cricket chirps; an owl hoots, and a gentle breeze glides through. For no obvious reason there is then a sudden chorus of the most diabolical noises and every creature that has any means of screeching, snorting, blowing, scraping or croaking joins in to ensure the greatest possible disturbance of the peace and one wonders how the same cold moonlight ever appeared so lifeless.

The river, with its water, shade, and concentration of game, also attracts the wily African poacher. In our travels we had seen signs of their activities, old carcases, bee-hives and 
platforms in trees. We were instinctively always on the look-out for fresh signs of these ruthless killers. For hundreds of years they have taken a heavy toll of elephant and rhino for their trophies; a simple process of sitting over a watering place or near a game track and shooting a poisoned arrow into the first suitable victim. If the unfortunate brute does not die quickly, the poachers merely watch the sky for the next few days so that the vultures can show them where to find the dead animal. Ivory is then smuggled out by devious means to the Coast and away by dhow to the East.

In the heat of the midday sun Warden Sheldrick, with his quick eye, spotted fresh human footprints in the sand. We at once deployed, and with the rangers following the tracks, we combed the banks. A shot rang out ahead and we raced the cars to investigate, only to see three dark figures scrambling like monkeys into the thick undergrowth beyond the palms. Warden Marshall drove his car straight up the bank and through the bush after the band. One of these poachers was so nonplussed seeing a vehicle on his heels-a noisy contraption which he had probably never seen at close quarters before-that he at once capitulated and was brought back triumphantly to the sand-bed.

Warden Sheldrick, while trying to cut off the other poachers ahead, flushed a herd of buffalo and had to spend some precious and awkward moments perched on an anthill while the buffalo stampeded. An intensive hunt ensued, but the other two poachers made good their escape, perhaps to our good fortune, since we discovered at the usual exchange of information after such an incident, that these poachers, on first contact with the leading ranger, had loosed a poisoned arrow at him and had only missed him by inches. The ranger with great restraint had fired his rifle in the air, although by the law of the bush, one would think he would have been justified in shooting back. He described the encounter with the usual dramatic gesticulations, shivering with excitement through the full length of his tall form and pointed to the arrow embedded deep in the sand, loaded with a full charge of poison.

Accepting that the other two poachers had out-manouvred us, we continued our journey down the river with the one poacher on board, plying him with questions not only about his own activities, but about game in general. A tiny wizened old man wearing only a flimsy dirty loin cloth, he was a great source of interest and information. These people live by their wits and although the actual killing of an elephant with a poisoned arrow 
to collect ivory for the great smuggling trade holds no great danger, they have to find means of getting food and protecting themselves against sudden attack by lions, rhino, buffalo or any other creature. Their long experience has taught them how in dry regions to select a suitable creeper and cut it to get water, or to tap a natural tank in a baobob tree, or to follow certain signs leading to a hidden waterhole. Along the river they have no difficulty and like the elephants they merely dig whenever they want a drink. They also live on and trade in honey, and each has his allotted zone of trees and carefully placed honey barrels. It seems to be a code of honour among these hunters that one will not rob the hive of another.

Further down the sand we found a honey barrel that had fallen out of a tree and bees were swarming round the freshly broken comb. The old man's eyes sparkled and we encouraged him to take the honey. He began to search for suitable wood which by rubbing a stick in a hole was his method of making fire, but to save time we offered a box of matches. This had little meaning to him and a ranger had to demonstrate the white man's magic of a chemical device. He then ignited a dry ball of elephant dung and when it was smouldering and smoking well, he wrapped his dirty old loin-cloth round his head and ventured otherwise naked straight into the swarm of angry bees. Again it seemed that by experience he knew that the most vulnerable part of his body was his neck and he also had an obvious belief that the bees would not sting him. With the smouldering dung in one hand, he quite calmly separated the combs, scraping off the stupefied bees and pausing now and then to have a good bite at the prize. With the natural politeness of wild men, he offered a comb to each of us, and after loading the rest on board we again sallied forth down the river. It was a simple performance, but remarkable in the skill with which the old poacher handled the situation, finishing his endeavours without a single sting.

Having achieved the object of our journey and reached the end of the motorable sand, we turned back to make camp. The old man was given food and made to sleep between the two rangers. The cicadas stopped hissing, the palms bade farewell to another day and we all soon drifted into heavy sleep only as one can with a feeling of pleasant fatigue and in the cool clean air of an African night.

As the dawn slowly broke through and forms of trees and rocks took on a more definite shape, I glanced towards the rangers and saw between them an empty space. There were the old man's sandals and his bow and arrows, but he had gone in 
the silence of the night, taking with him only his knife and his calabash, presumably quite confident that he could fend for himself and soon find his pals. I could not help admitting to myself, though not perhaps to the others, that I had a sneaking feeling of relief that this old man got away ; the greatest enemy of preservation, a merciless killer of God's great beasts, but in spite of his frail form and wizened appearance, a man of the wilds. 